\title{
Molecular diagnostic methods for detection of Thelohania contejeani (Microsporidia), the causative agent of porcelain disease in crayfish
}

\author{
M. El-Matbouli* ${ }^{*}$ H. Soliman \\ Institute of Zoology, Fish Biology and Fish Diseases, Faculty of Veterinary Medicine, University of Munich, \\ Kaulbachstraße 37, 80539 Munich, Germany
}

\begin{abstract}
Diagnosis of Thelohania contejeani in the crayfish Astacus astacus is currently based on observation of gross clinical signs - opaque appearance of the abdomen and whitish colouration of the musculature - and confirmed by microscopic examination of histological sections of muscle. We have developed 2 molecular diagnostic methods for sensitive and rapid detection of porcelain disease in its early stages: PCR and loop-mediated isothermal amplification (LAMP). The PCR test utilises a primer based on the $T$. contejeani small subunit ssu ribosomal RNA (ssu rRNA) gene and amplified parasite DNA with high specificity and a detection limit of $10^{-5}$ dilution. The LAMP assay involves incubation of the target DNA with a set of 6 primers and Bst DNA polymerase for 60 min at $65^{\circ} \mathrm{C}$ in a water bath or heating block, followed by visualisation of the reaction products with the SYBR Green I stain; sensitivity of visual detection with SYBR Green I is equivalent to that with agarose gel electrophoresis. The LAMP assay can detect $T$. contejeani DNA to a dilution of $10^{-7}$. The LAMP assay is 100 times more sensitive than the PCR test and is the method we recommend as an alternative to traditional means of diagnosing $T$. contejeani.
\end{abstract}

KEY WORDS: Thelohania contejeani $\cdot$ PCR $\cdot$ Loop-mediated isothermal amplification · Diagnosis · Crayfish

Resale or republication not permitted without written consent of the publisher

\section{INTRODUCTION}

Thelohaniasis, or porcelain disease, is a significant disease, which affects a number of decapod crustaceans, including freshwater crayfish. It is caused by the microsporidian parasite Thelohania contejeani (Sprague \& Couch 1971), and was originally described in Europe by Henneguy \& Thelohan (1892) as the causative agent of a disease which resulted in heavy losses in crayfish populations. T. contejeani infects 2 European crayfish species, Astacus astacus (Schäperclaus 1954, Sumari \& Westman 1969, Voronin 1971) and Austropotamobius pallipes (Dollfus 1935, Pixell Goodrich 1956, Vey \& Vago 1973). The disease has also been reported in several crayfish species from different countries (McGriff \& Modin 1983).

According to Kudo (1924) and BykhovskayaPavlovskaya et al. (1964), crayfish become infected through ingestion of Thelohania contejeani spores.
The amoeboid germ of the spore then emerges, penetrates the gut, and reaches the muscle tissue via the haemocoele. Asexual reproduction takes place in the muscle, which leads to a dramatic increase in parasite cells. Finally, pansporoblasts develop and transform directly into sporoblasts containing 8 spores, which can be released upon rupture of the sporoblast membrane. Lom et al. (2001) reported that $T$. contejeani has 2 simultaneous routes of sporogony: either diplokaryotic sporonts produce 8 uninucleated spores with 9 to 10 turns of the polar tube within a sporophorous vesicle wall, or single diplokaryotic sporonts produce small membrane-bound compartments, in which they transform into mature diplokaryotic spores with 5 to 6 turns of the polar tube.

Thelohania contejeani infects both juvenile and adult crayfish of either sex. Infection causes the abdominal muscles to appear opaque and milky due to spore production, as opposed to healthy muscle which is grey and 
translucent. With advanced infection, the crayfish appear sluggish and the tail-flick escape reaction is incompetent (Cossins \& Bowler 1974, Alderman \& Polglase 1988). T. contejeani can cause considerable mortality in both natural and artificially reared crayfish populations (Henneguy \& Thelohan 1892, Vey \& Vago 1972).

Diagnosis of porcelain disease has traditionally relied on observation of gross clinical signs - the white musculature and opaque abdomen - followed by observation of pansporoblasts ( $5 \mu \mathrm{m}$ diameter) in histological muscle sections (Bower et al. 1994). Nevertheless, in early stages of the disease, clinical signs can be either difficult to observe, or entirely absent (Bower et al. 1994); hence, there is a great demand for a rapid, sensitive and specific technique for diagnosis of Thelohania contejeani to protect crayfish populations by restricting spread of the disease.

DNA-based detection methods are increasingly being developed for diagnosis of pathogens. One molecular method, polymerase chain reaction (PCR), is now a standard technique in molecular biology for amplification and identification of specific DNA fragments. A second, novel DNA-based diagnostic approach, loopmediated isothermal amplification (LAMP), was originally developed by Notomi et al. (2000) for rapid amplification of DNA with high specificity and efficiency under isothermal conditions. LAMP can amplify a few copies of DNA to $10^{9}$ copies in $<1 \mathrm{~h}$ under isothermal conditions (Thekisoe et al. 2005). In addition, a LAMP reaction can be easily determined positive by the naked eye, without agarose gel electrophoresis (Mori et al. 2001, Iwamoto et al. 2003, El-Matbouli \& Soliman 2005a,b, Soliman \& El-Matbouli 2005).

The aim of this work was to develop and compare advanced, sensitive, specific and rapid diagnostic assays to detect presporogonic stages of Thelohania contejeani in crayfish using PCR and LAMP methods.
Thelohania contejeani spores using a QIAamp DNA mini kit (QIAGEN). Infected tissue was thoroughly homogenised in liquid nitrogen, and $20 \mathrm{mg}$ of tissue powder was then transferred to a $2 \mathrm{ml}$ microcentrifuge tube, also in liquid nitrogen. We added $180 \mu \mathrm{l}$ of lysis buffer and $20 \mu \mathrm{l}$ of Proteinase $\mathrm{K}$ to the powder followed by incubation at $56^{\circ} \mathrm{C}$ for 1 to $3 \mathrm{~h}$. DNA was then extracted according to the manufacturer's instructions, eluted with nanopure water, and stored at $-20^{\circ} \mathrm{C}$.

Oligonucleotides. A set of 6 primers was designed for LAMP based on the Thelohania contejeani small subunit ribosomal RNA gene (ssu rDNA) (GenBank Accession No. AF 492593). This set of primers consisted of 2 outer primers (F3 and B3), 2 inner primers (forward inner primer FIP, and reverse inner primer, BIP) and 2 loop primers (LoopF and LoopB).

FIP contained the complementary sequence of F1 primer (24 nt), TTTT linker and sense sequence of F2 primer (22 nt): 5'-CCTTAGACCTAGTAGCCATCT CTCTTTTTACGTAGGCGATGACGGGTAAC-3'; BIP contained the sense sequence of B1 (21 nt), TTTT linker and the antisense sequence of B2 (20 nt): 5'-AGC AGGCGCGAAACTTACCCCTTTTGGCTGC TGGCACCAGACTTG-3'. F3 primer (22 nt): 5'-AGCTAGTATGTAGG GTAA GGGC-3'; and B3 primers (22 nt): 5'-ACTCTT GGAGC TGGAATTACCG-3'.

To accelerate the LAMP reaction, 2 loop primers were constructed: LoopF (22 nt) 5'-CCGGAATAGAACCCTAATTCCC-3', and LoopB (28 nt) 5'-TGCTATTTAGTAGTGAGGTAGTTATAAG-3'. The location of the LAMP primers on the DNA sequence is illustrated in Fig. 1. The LAMP outer forward primer F3 and the reverse primer B3 were used for the standard PCR reaction to amplify a $261 \mathrm{bp}$ fragment.

\section{MATERIALS AND METHODS}

Isolation of Thelohania contejeani spores and DNA extraction. In the present study we used 17 freshwater crayfish naturally infected with Thelohania contejeani, and 5 uninfected indidviduals from the same population. Highly infected abdominal muscle was dissected out of the diseased crayfish and pulped with a scalpel. The resultant spore suspension was pressed through a $10 \mu \mathrm{m}$ filter, using a pestle, to separate spores from muscle tissue. The spores were then washed several times with double-distilled water through repeated centrifugation at $4000 \times g$ for $2 \mathrm{~min}$.

DNA was extracted directly from infected crayfish muscle tissues and from separated
F3 F2 TAGAATAAGAGATTGACCTATCAGCTAGTATGTAGGGTAAGGGCCTACGTAGG LoopF GCGATGACGGGTAAC GGGGAATTAGGGTTCTATTCCGG AGAAGGAGGCTG F1 B1 A GA GATGGCTACTAGGTCTAAGG AGAGCAGCAGGCGCGAAACTTACCCC LoopB GCTATTTAGTAGTGAGGTAGTTATAAG AAGTAGTGAATGTATTTTAC TGATT

B2 TTCCTTGTAAATATAGGAAATGATAATTGGAGGGCAAGTCTGGTGCCAGCAGC B3 CGCGGTAATTCCAGCTCCAAGAGT

Fig. 1. Thelohania contejeani. (GenBank Accession No. AF 492593) Partial ssu rDNA sequence used to construct the inner and outer primers (in italics). Inner primers FIP and BIP comprise complementary sequence to F1 and sense sequence of F2, and sense sequence of B1 and complementary sequence of B2, respectively 
LAMP reaction. The LAMP reaction for detection of Thelohania contejeani was carried out in $25 \mu \mathrm{l}$ final volume comprising $20 \mathrm{mM}$ Tris- $\mathrm{HCl}(\mathrm{pH} 8.8), 10 \mathrm{mM}$ $\mathrm{KCl}, 5 \mathrm{mM} \mathrm{MgSO}{ }_{4}, 10 \mathrm{mM}\left(\mathrm{NH}_{4}\right)_{2} \mathrm{SO}_{4}, 0.1 \%$ Triton $\mathrm{x}-100,1.6 \mathrm{M}$ betaine, deoxynucleotide triphosphates (2.8 mM each), $1.6 \mu \mathrm{M}$ each of FIP and BIP, $0.8 \mu \mathrm{M}$ each of loop-F and loop-B, $0.2 \mu \mathrm{M}$ each of F3 and B3 primers, 8U Bst DNA polymerase (New England BioLabs), $2 \mu$ template DNA and $25 \mu$ distilled water. DNA template was omitted from the negative control reaction. The mixture was incubated at $65^{\circ} \mathrm{C}$ for different periods (10 to $60 \mathrm{~min}$, in $5 \mathrm{~min}$ increments). After incubation, the reaction was terminated by heating at $80^{\circ} \mathrm{C}$ for $2 \mathrm{~min}$. Different concentrations and combinations of the primers FIP, BIP, F3 and B3 were tested with and without the $F$ and $B$ loop primers.

Detection of LAMP products. For visual detection, $1 \mu \mathrm{l}$ of 1:10 diluted SYBR Green I nucleic acid gel stain, $10000 \times$ concentration in DMSO (Cambrex Bio Science) was added to the reaction mixture and any colour change noted.

For agarose gel electrophoresis, $2 \mu$ l of the reaction mixture was loaded on an ethidium bromide $(1 \mathrm{mg}$ $\mathrm{ml}^{-1}$ ) -stained $2 \%$ agarose gel, electrophoresed, and then photographed under UV light. A 100 bp DNA ladder (Cambrex Bio Science) was used as a molecular weight marker.

PCR. PCR was performed in a $50 \mu$ reaction mixture containing $46 \mu \mathrm{l} 1.1 \times$ ReadyMix PCR Master mix (AB Gene) comprising $75 \mathrm{mM}$ Tris- $\mathrm{HCl}$ (pH 8.8), $20 \mathrm{mM}\left(\mathrm{NH}_{4}\right)_{2} \mathrm{SO}_{4}, 1.5 \mathrm{mM} \mathrm{MgCl}, 0.01 \%$ Tween 20, $0.2 \mathrm{mM}$ each of dATP, dCTP, dGTP, dTTP, 1.25 U Taq DNA polymerase and red dye for electrophoresis, and $4 \mu \mathrm{l}$ template DNA with forward and reverse primers (F3 and B3). A gradient PCR was conducted to determine optimal primer annealing temperature, and different concentrations of forward and reverse primers were tested.

The PCR products were analysed on a $1.5 \%$ agarose gel, stained with ethidium bromide, and then visualised under UV light. A 100 bp DNA ladder (Cambrex Bio Science) was used as molecular weight marker.

Cloning and sequencing of Thelohania contejeani PCR products. For sequencing, DNA fragments (261 bp) were separated from excess primers and unincorporated nucleotides using the MinElute gel extraction kit (QIAGEN), and then cloned into the $\mathrm{pCR}^{\circledR} \quad 4-\mathrm{TOPO}^{\circledR}$ vector using a TOPO TA cloning ${ }^{\circledR}$ kit for sequencing (Invitrogen), as per the manufacturer's instructions. Recombinant plasmids were purified from E. coli using a Fast plasmid mini kit (Eppendorf AG), following the manufacturer's instructions. Plasmid concentrations were determined by a spectrophotometer (Eppendorf biophotometer). Cloned PCR products were sequenced in a commercial sequencing laboratory (SEQLAB), and then compared with the type $T$. contejeani ssu rRNA gene sequence.

Specificity of LAMP and PCR reactions. The specificity of the LAMP and PCR assays for sole amplification of Thelohania contejeani was appraised by testing it against DNA from other Thelohania speciesT. montirivulorum, T. solenopsae and non-infected crayfish muscle.

Sensitivity of LAMP and PCR assays. The sensitivity of the LAMP and PCR assays was compared using 10-fold serial dilutions of Thelohania contejeani template DNA to determine the lower detection limit of each test.

\section{RESULTS}

\section{Optimisation of reaction conditions for detection of Thelohania contejeani by LAMP}

Preliminary optimisation of the LAMP assay was carried out using Primers FIP, BIP, F3 and B3. The reaction mix was incubated at temperatures from 60 to $65^{\circ} \mathrm{C}$ for

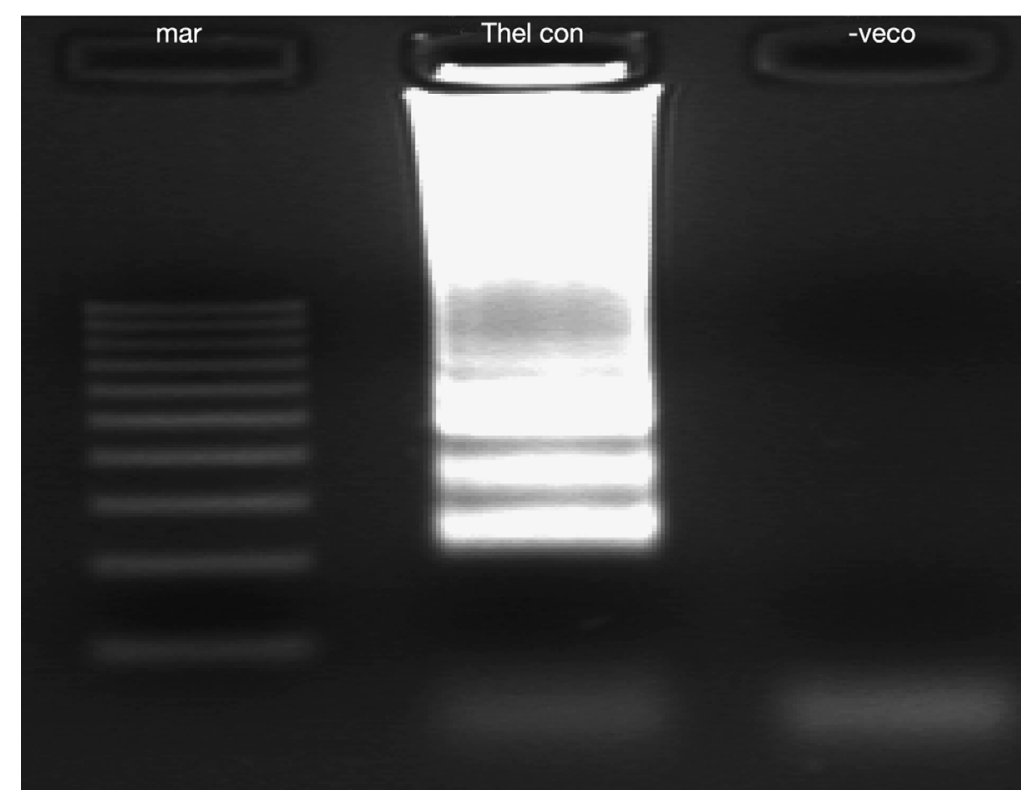

Fig. 2. Thelohania contejeani. Agarose gel showing LAMP amplification products of $T$. contejeani DNA, which appears as multiple bands of different molecular weights. Lanes: mar $=100 \mathrm{bp}$ DNA molecular weight standard; Thel con $=T$. contejeani products using Primers FIP, BIP, F3, B3, LoopF, LoopB $;-$ veco $=$ no template negative control 
$60 \mathrm{~min}$; the optimum temperature of the LAMP assay was $65^{\circ} \mathrm{C}$, at which temperature bands were especially clear (Fig. 2). The optimal reaction time, using the 4 primers, was $45 \mathrm{~min}$ at $65^{\circ} \mathrm{C}$ for detection of amplification products (data not shown). Addition of the 2 loop primers, $\mathrm{F}$ and $\mathrm{B}$, resulted in amplification products which were detected as early as $25 \mathrm{~min}$ at $65^{\circ} \mathrm{C}$ (Fig. 3). On the gel, the LAMP products appeared as multiple bands of different molecular weight up to the loading well (Fig. 2). The sensitivity of detection of the products visually, with SYBR Green I, was equivalent to that of agarose gel electrophoresis; addition of SYBR Green I to the reaction tubes produced a green colour for positive samples while the negative control samples remained orange (Fig. 4). In summary, the LAMP assay was optimised to detect Thelohania contejeani with high sensitivity by incubation with all 6 primers at $65^{\circ} \mathrm{C}$ for $60 \mathrm{~min}$.

\section{Optimisation of reaction conditions for detection of Thelohania contejeani by PCR}

The best amplification of the specific 261 bp DNA fragment (Fig. 5) was achieve under the following conditions: 10 pmol from each primer (F3 and B3) with cycling conditions comprising initial denaturation at $96^{\circ} \mathrm{C}$ for $5 \mathrm{~min}$, followed by 38 cycles of denaturation at $95^{\circ} \mathrm{C}$ for $45 \mathrm{~s}$, primer annealing at $66^{\circ} \mathrm{C}$ for $45 \mathrm{~s}$, and extension at $72^{\circ} \mathrm{C}$ for $45 \mathrm{~s}$, with a final elongation step at $72^{\circ} \mathrm{C}$ for $5 \mathrm{~min}$.

Cloning and sequencing of the $261 \mathrm{bp}$ PCR product revealed $100 \%$ homology with the ssu rRNA gene of Thelohania contejeani in GenBank.

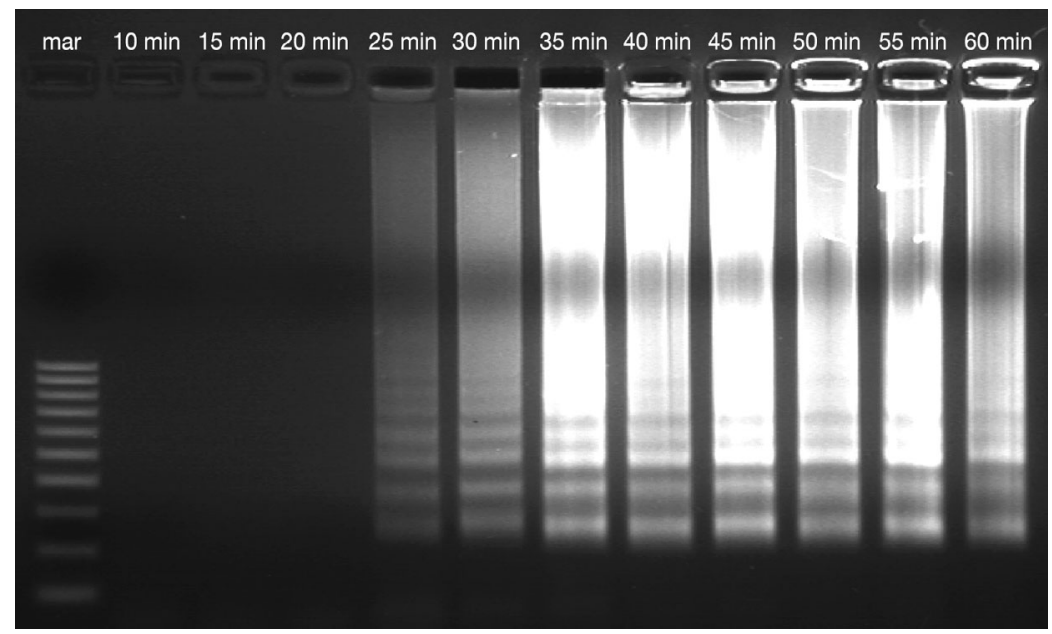

Fig. 3. Thelohania contejeani. Agarose gel showing effect of varying amplification time in T. contejeani-LAMP reaction. Amplification using Primers FIP, BIP, F3, B3, LoopF and LoopB was carried out at $65^{\circ} \mathrm{C}$ for time periods indicated. mar $=100 \mathrm{bp}$ DNA molecular weight standard. T. contejeani DNA was

\footnotetext{
detectedable as early as $25 \mathrm{~min}$
}

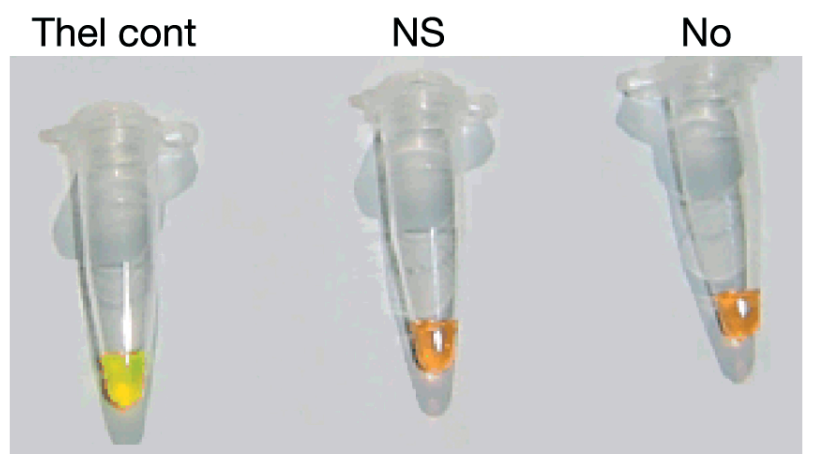

Fig. 4. Thelohania contejeani. Appearance of LAMP products visualised with SYBR Green I stain. Thel cont = reaction positive for $T$. contejeani, green colouration; NS = negative reaction, orange colouration; $\mathrm{NO}=$ no template (negative control)

\section{Specificity of LAMP and PCR assays to Thelohania contejeani}

Both the LAMP and PCR assays amplified Thelohania contejeani DNA only, with no reaction to T. montirivulorum, T. solenopsae, un-infected crayfish or the no-template negative control (Figs. 6 \& 7).

\section{Sensitivity of LAMP and PCR assays}

A 10-fold serial dilution of Thelohania contejeani DNA revealed the detection limits of the reactions (Fig. 8): the LAMP assay detected down to a dilution of $10^{-7}$ while the PCR detected only to a dilution of $10^{-5}$.

\section{DISCUSSION}

Crayfish are of ecological and economic importance, as their flesh is edible and large quantities are consumed in many countries. Freshwater crayfish farming is expanding around the world. The microsporidian parasite Thelohania contejeani has impacted crayfish populations and caused economic losses to the industry. The parasite infects the crayfish musculature, with no visible symptoms of disease until infection has progressed to the point where the abdominal muscle tissue is white and opaque. These physical signs only appear during the final stages of the disease, and are rapidly followed by loss of muscle function and death. Hence, early recognition of the disease and its subsequent eradication 


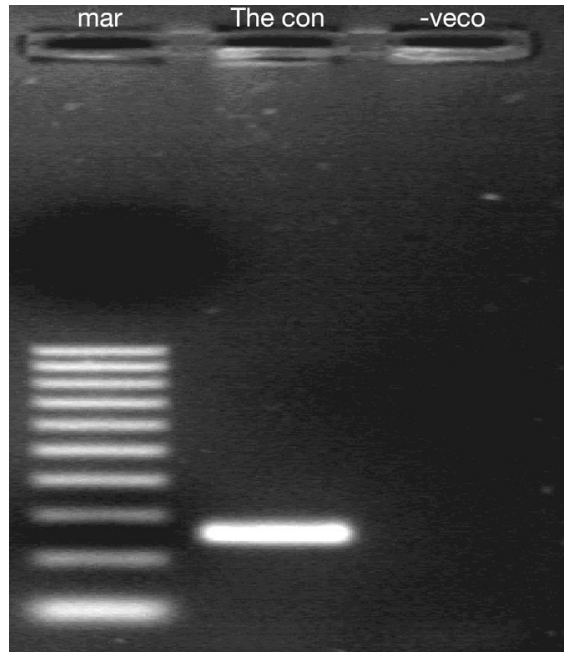

Fig. 5. Thelohania contejeani. Agarose gel showing PCR product of DNA. The primers used, F3 and B3, amplified the $261 \mathrm{bp}$ DNA fragment of $T$. contejeani, while there was no amplification in the negative control. Lanes: $\operatorname{mar}=100 \mathrm{bp}$ DNA molecular weight standard; The con $=T$. contejeani $\mathrm{DNA}_{i}-\mathrm{veco}=$ negative control

is essential in maintaining a viable and productive farm (Cossins 1973). Given a lack of methods for diagnosing porcelain disease in its early stages, we have developed 2 molecular assays for sensitive detection of T. contejeani.

Molecular techniques provide rapid and sensitive ways to diagnose disease, and often overcome the shortcomings of traditional diagnostic methods. PCR assays facilitate diagnosis by direct visualisation of specific bands on ethidium bromide-stained gels; this is easier and faster than processing samples for histological examination. We have developed a PCR assay for diagnosis of Thelohania contejeani which employs forward and reverse primers constructed from the ssu rRNA gene. The assay was optimised with respect to primer concentration, annealing temperature and other parameters for detection of $T$. contejeani DNA with high specificity and sensitivity. The assay does not detect DNA of other closely related Thelohania species, and can detect $T$. contejeani DNA to a dilution of $10^{-5}$; it is more highly sensitive than traditional methods of diagnosing porcelain disease.

A novel molecular diagnostic technique was also developed for isothermal amplification of Thelohania contejeani DNA by LAMP assay. LAMP assays have been used previously for rapid diagnosis of the causative agents of different diseases which affect aquaculture (Caipang et al. 2004, Gunimaladevi et al. 2004, 2005, Kono et al. 2004, Savan et al. 2004, El-Matbouli \& Soliman 2005a,b, Soliman \& El-Matbouli 2005). Our LAMP assay was optimised to amplify $T$. conte-

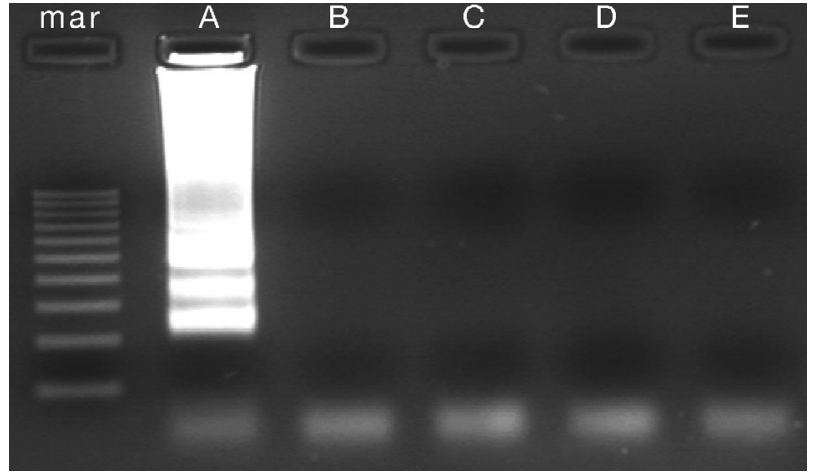

Fig. 6. Thelohania contejeani. Agarose gel electrophoresis, demonstrating specificity of LAMP for T. contejeani. LAMP reaction was carried out at $65^{\circ} \mathrm{C}$ for $1 \mathrm{~h}$ using a set of 6 primers. Lanes: $\operatorname{mar}=100 \mathrm{bp}$ molecular weight marker; $\mathrm{A}=$ amplification products of $T$. contejeani DNA; $\mathrm{B}=$ no amplification of T. montirivulorum; $\mathrm{C}=$ no amplification of T. solenopsae; $\mathrm{D}=$ no amplification of uninfected crayfish $\mathrm{DNA}_{;} \mathrm{E}=$ no amplification of no-template control

jeani DNA using a set of 6 primers incubated at $65^{\circ} \mathrm{C}$ for $60 \mathrm{~min}$ in the presence of a Bst DNA polymerase enzyme. Although the LAMP assay required only 4 primers, 2 outer and 2 inner, that recognise 6 different regions of the target sequence (Notomi et al. 2000), addition of 2 loop primers was found to enhance and accelerate the reaction, and increase not only the sensitivity but also the specificity of the assay. The 6 primers recognised 8 distinct regions of the target DNA, which minimised the probability of false positive results (Nagamine et al. 2002, Maeda et al. 2005). Although the LAMP assay could detect T. contejeani

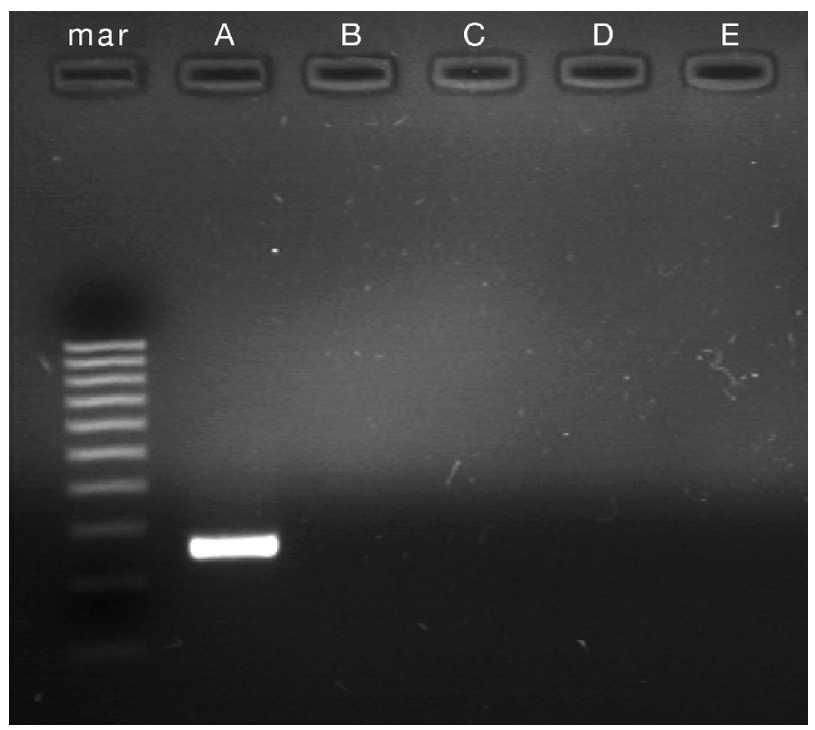

Fig 7. Thelohania contejeani. Agarose gel electrophoresis demonstrating specificity of PCR for T. contejeani. Other details as in Fig. 6 


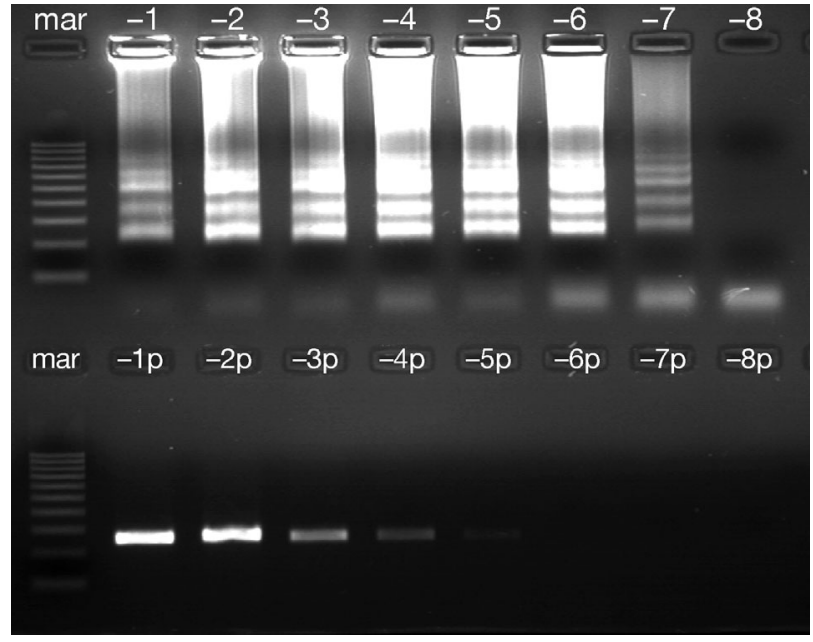

Fig. 8. Thelohania contejeani. Agarose gel showing lower detection limits of LAMP and PCR using 10-fold serial dilutions of template DNA. LAMP reaction detected T. contejeani DNA at a dilution of $10^{-7}$, while PCR amplified a $261 \mathrm{bp}$ product and detected T. contejeani DNA at a dilution of $10^{-5}$. Lanes: mar $=100 \mathrm{bp}$ DNA molecular weight standard $;-1,-1 \mathrm{p}$ $=$ template concentration $10^{-1} ;-2,-2 \mathrm{p}=10^{-2} ;-3,-3 \mathrm{p}=10^{-3}$; $-4,-4 \mathrm{p}=10^{-4} ;-5,-5 \mathrm{p}=10^{-5} ;-6,-6 \mathrm{p}=10^{-6} ;-7,-7 \mathrm{p}=10^{-7}$; $-8,-8 \mathrm{p}=10^{-8}$

DNA in as little as 25 min (Fig. 3), we consider 60 min to be an optimal time to ensure visual detection of very low amounts of $T$. contejeani DNA; this is in accordance with the findings of Mori et al. $(2001,2004)$. In general, the LAMP method yielded an extremely large amount of DNA, and hence facilitated simple nakedeye inspection (Mori et al. 2001, Iwamoto et al. 2003), whereby positive samples turn green and negative samples remain orange (Fig. 4.). The sensitivity of visual detection was equivalent to that with agarose gel electrophoresis. Visual inspection has the advantages that it is simple, rapid, sensitive and requires neither post-amplification of products nor use of hazardous materials such as ethidium bromide. Thus, the LAMP assay is entirely suitable for use in a small laboratory or clinic.

The lower detection limit of the LAMP assay was $10^{-7}$ dilution of Thelohania contejeani DNA; this was superior to the PCR test which could detect down to $10^{-5}$ dilution. The lower sensitivity of the PCR assay (100 times less than LAMP) may be attributable to the presence of inhibitors in the samples (Ibrahim et al. 1992, Kalinina et al. 1997, Wilson 1997); the sensitivity of LAMP is not influenced by the presence of nontarget DNA in samples (Notomi et al. 2000).

Our results indicate that the LAMP assay is a better alternative than PCR to traditional means for diagnosis of Thelohania contejeani. It detects parasite DNA with high sensitivity and requires only low-cost equipment (water bath or heating block) instead of the thermacycler and electrophoresis equipment needed for PCR. Further, as LAMP is an isothermal reaction, the reaction time is very short (60 min) and direct visual detection of LAMP reaction products is possible, requiring less labour than gel electrophoresis. We recommend the LAMP assay as a rapid diagnostic method for detection of the early stages of $T$. contejeani in asymptomatic crayfish.

\section{LITERATURE CITED}

Alderman DJ, Polglase JL (1988) Pathogens, parasites and commensals. In: Holdich DM, Lowery RS (eds) Freshwater crayfish. Biology, management and exploitation. Croom Helm, London, p 167-212, 426-479

Bower SM, McGladdery SE, Price IM (1994) Synopsis of infectious diseases and parasites of commercially exploted shellfish. Annu Rev Fish Dis 4:1-199

Bykhovskaya-Pavlovskaya IE, Gusev AV, Dubinina MN, Izyumova AA and 5 others (1964) Key to parasites of freshwater fish of the USSR. Israel Program for Scientific Translations, Jerusalem (Translation)

Caipang CMA, Haraguchi I, Ohira T, Hirono I, Aoki T (2004) Rapid detection of a fish iridovirus using loop-mediated isothermal amplification (LAMP). J Virol Methods 121: 155-161

Cossins AR (1973) Thelohania contejeani Henneguy, microsporidian parasite of Austropotamobius pallipes Lereboullet: an histological and ultrastructural study. Freshw Crayfish 2:151-164

Cossins AR, Bowler K (1974) An histological and ultrastructural study of Thelohania contejeani Henneguy, 1892 (Nosematidae), microsporidian parasite of the crayfish Austropotamobius pallipes Lereboullet. Parasitology 68: 81-91

Dollfus RP (1935) Thelohanose de l'ecrivisse (Astacus pallipes, Lereboullet), a`Richelieu (Indre-et-Loire). Bull Soc Cent Aquic Pêche 42:119-122

El-Matbouli M, Soliman H (2005a) Rapid diagnosis of Tetracapsuloides bryosalmonae, the causative agent of proliferative kidney disease (PKD) in salmonid fish by a novel DNA amplification method, loop-mediated isothermal amplification (LAMP). Parasitol Res 96:277-284

El-Matbouli M, Soliman H (2005b) Development of a rapid assay for diagnosis of whirling disease in fish and oligochaetes using loop-mediated isothermal amplification. J Fish Dis 28:549-557

Gunimaladevi I, Kono T, Venugopal MN, Sakai M (2004) Detection of koi herpesvirus in common carp, Cyprinus carpio L., by loop-mediated isothermal amplification. J Fish Dis 27:583-589

Gunimaladevi I, Kono T, LaPatra SE, Sakai M (2005) A loopmediated isothermal amplification (LAMP) method for detection of infectious hematopoietic necrosis virus (IHNV) in rainbow trout (Oncorhynchus mykiss). Arch Virol 150:899-909

Henneguy F, Thelohan P (1892) Myxosporidies parasites des muscles chez quelques crustaces decapods. Ann Micrograph 4:617-641

Ibrahim A, Liesack W, Stackebrandt E (1992) Polymerase chain reaction-gene probe detection system specific for pathogenic strains of Yersinia enterocolitica. J Clin Microbiol 30:1942-1947 
Iwamoto T, Sonobe T, Hayashi K (2003) Loop-mediated isothermal amplification for direct detection of $\mathrm{Myco}$ bacterium tuberculosis complex, M. avium, and $M$. intracellulare in sputum samples. J Clin Microbiol 41: $2616-2622$

Kalinina O, Lebedeva I, Brown J, Silver J (1997) Nanoliter scale PCR with TaqMan detection. Nucleic Acids Res 25: $1999-2004$

Kono T, Savan R, Sakai M, Itami T (2004) Detection of white spot syndrome virus in shrimp by loop-mediated isothermal amplification. J Virol Methods 115:59-65

Kudo R (1924) A biologic and taxonomic study of the Microsporidia. Ill Biol Monogr 9:1-268

Lom J, Nilsen F, Dykova I (2001) Thelohania contejeani Henneguy, 1892: dimorphic life cycle and taxonomic affinities, as indicated by ultrastructural and molecular study. Parasitol Res 87:860-872

Maeda H, Kokeguchi S, Fujimoto C, Tanimoto I, Yoshizumi W, Nishimura F, Takashiba S (2005) Detection of periodontal pathogen Porphyromonas gingivalis by loopmediated isothermal amplification method. FEMS Immunol Med Microbiol 43:233-239

McGriff D, Modin J (1983) Thelohania contejeani parasitism of the crayfish, Pacifastacus leniusculus, in California. Calif Fish Game 69:178-183

Mori Y, Nagamine K, Tomita N, Notomi T (2001) Detection of loop-mediated isothermal amplification reaction by turbidity derived from magnesium pyrophosphate formation. Biochem Biophys Res Commun 289:150-154

Mori Y, Kitao M, Tomita N, Notomi T (2004) Real-time turbidimetry of LAMP reaction for quantifying template DNA. J Biochem Biophys Methods 59:145-157

Nagamine K, Hase T, Notomi T (2002) Acceleration reaction by loop-mediated isothermal amplification using loop primers. Mol Cell Probes 16:223-229

Editorial responsibility: Dieter Steinhagen,

Hannover, Germany
Notomi T, Okayama H, Masubuchi H, Yonakawa T, Watanabe K, Amino K, Hase T (2000) Loop-mediated isothermal amplification of DNA. Nucleic Acids Res 28:e63

Pixell Goodrich H (1956) Crayfish epidemics. Parasitology 46 : $480-483$

Savan R, Igarashi A, Matsuoka S, Sakai M (2004) Sensitive and rapid detection of edwardsiellosis in fish by a loopmediated isothermal amplification method. Appl Environ Microbiol 70:621-624

Schäperclaus W (1954) Fischkrankheiten, Akademie-Verlag, Berlin

Soliman H, El-Matbouli M (2005) An inexpensive and rapid diagnostic method of koi herpesvirus (KHV) infection by loop-mediated isothermal amplification. Virol J 2:83

Sprague V, Couch J (1971) An annotated list of protozoan parasites, hyperparasites, and commensals of decapod Crustacea. J Protozool 18:526-537

Sumari O, Westman K (1969) The crayfish parasite Thelohania contejeani Henneguy (Sporozoa, Microsporidia) found in Finland. Ann Zool Fenn 7:193-194

Thekisoe OMM, Inoue N, Kuboki N, Tuntasuvan D, Bunnoy W, Borisutsuwan S, Igarashi I, Sugimoto C (2005) Evaluation of loop-mediated isothermal amplification (LAMP), PCR and parasitological tests for detection of Trypanosoma evansi in experimentally infected pigs. Vet Parasitol 130:327-330

Vey A, Vago C (1972) Researches sur les maladies actuelles des ecrevisses en France. Ann Hydrobiol 3:59-64

Vey A, Vago C (1973) Protozoan and fungal diseases of Austropotamobius pallipes Lereboullet in France. Freshwater crayfish. Freshw Crayfish 2:165-179

Voronin VN (1971) New data on microsporidiosis of the crayfish, Astacus astacus (L. 1758). Parazitologia 5:186-191

Wilson IG (1997) Inhibition and facilitation of nucleic acid amplification. Appl Environ Microbiol 63:3741-3751

Submitted: October 13, 2005; Accepted: November 11, 2005 Proofs received from author(s): March 3, 2006 